\title{
Journal of Food and Health Science
}

E-ISSN 2149-0473

\section{HIGH HYDROSTATIC PRESSURE TREATMENT OF FRUIT, FRUIT PRODUCTS AND FRUIT JUICES: A REVIEW ON PHENOLIC COMPOUNDS}

\author{
Müzeyyen BERKEL KAŞIKCI, Neriman BAĞDATLIOĞLU \\ Department of Food Engineering, Faculty of Engineering, Celal Bayar University, Manisa, Turkey
}

Received: 30.09 .2015

Accepted: 13.11 .2015

Published online: 19.11.2015

\section{Corresponding author:}

Müzeyyen BERKEL KASSIKCI, Department of Food Engineering, Faculty of Engineering, Celal Bayar University, Manisa, Turkey

E-mail: muzeyyen.berkel@cbu.edu.tr

\begin{abstract}
:
Phenolic compounds are healthy substances, therefore amount of phenolic compounds in fruits/fruit juices are important for customers. Flavonoids are the most common and widely distributed group of plant phenolics. Fruits and fruit juices are among the best sources of polyphenols in the human diet because of their high content in most fruits. Processing fruits can change their content of phenolic compounds and heat treatments usually decrease phenolic compounds in fruits. Minimising losses of these bioactive compounds during processing and storage are one of the priorities and challenge for manufacturers. High hydrostatic pressure (HHP) is a technology which can be used instead of thermal process such as pasteurization and can be combined with thermal process for sterilization. This study discusses the impact of HHP processing
\end{abstract}

conditions on the stability of phenolic compounds in fruits and their products after process, during storage and compares with thermal process. Matrix of food and processing parameters such as pressure, temperature, time are important for retaining of phenolic compounds. In general, several authors have proven that HHP treatment on different fruit products slightly modified their content of phenolic compounds. There has not been much research comparing HHP with thermal processes on effects of phenolic compounds in fruits and fruit products, and researches generally indicate that HHP is better than thermal processes on retaining phenolic compounds.

Keywords: Polyphenol, High hydrostatic pressure, Fruit, Anthocyanin, Thermal treatment 


\section{Introduction}

Consumers are interested in the nutritional and health-related characteristics of fruits and vegetables. Phenolic compounds are healthy substances, so amount of phenolic compounds in fruit and vegetable products is important for customers. Over the past decade much research has been carried out on plant phytochemicals and their positive health effects. It has been demonstrated that a diet rich in fruits and vegetables containing various classes of polyphenols (phenolic acids, flavonols, catechin monomers, proanthocyanidins, flavones, flavanones, and anthocyanins) decreases the risk of premature mortality, cardiovascular disorders, advancing age-induced oxidative stress, inflammatory responses and diverse degenerative diseases (Michels et al., 2000; Torres et al. 2011; Sánchez-Moreno et al. 2009).

Flavonoids are the most common and widely distributed group of plant phenolics. Among them, flavones, flavonols, flavanols, flavanones, anthocyanins, and isoflavones are particularly common in fruits. Fruits are among the best sources of polyphenols in the human diet because of their high content in most fruits and the relatively large serving sizes (100-200 g).

High hydrostatic pressure (HHP) is a technology which subject's liquid and solid foods, with or without packaging, to pressures between 100 and $800 \mathrm{MPa}$. Process temperature during pressure treatment can be specified from below $0^{\circ} \mathrm{C}$ (to minimize any effects of adiabatic heat) to above $100^{\circ} \mathrm{C}$. High pressure processing (HPP), is also described as high hydrostatic pressure (HHP), or ultra high pressure (UHP) processing in literature (FDA, 2015).

HHP technology can be used for various purposes such as pasteurization, extraction and osmotic dehydration. HHP technology can be combined with other thermal and non-thermal technologies such as ultrasound, pulsed electrical field (PEF), gamma-irradiation etc., which are excluded in this paper. This paper aims to provide a detailed and critical review of the latest applications of HHP on fruit and fruit juices, the effect of HHP on phenolic compounds are especially emphasized.

\section{Thermal Processing and HHP}

Thermal processing, which is the conventional method for the inactivation of plant enzymes and inhibition of microorganisms, is not suitable for soft fruits. In addition to desirable effect of microbial and enzyme inactivation, it results in the loss of physicochemical and nutritional quality attributes of the product. The color and flavor of most fruits deteriorate during thermal processing. As a consequence, the addition of artificial color is usually necessary during thermal processing of fruits (Burrows, 2001).

The application of HHP has the potential to produce high quality fruits that display characteristics of fresh foods, are microbiologically safe and extended shelf life (Huang et al., 2013). HHP preserves nutritional value with a minimal effect on the product quality and sensory properties of fruits and vegetables, since low molecular weight food compounds, such as flavoring agents, pigments, and some vitamins are not altered, because covalent bonds are not affected by pressure (Oey et al., 2008; Bala et al., 2008; Ramirez at al., 2009). Over the last years, HHP has been investigated and several commercial products, including fruit juices, i.e mandarin, grapefruit, apple, orange, carrot juices and broccoli-apple juice mixture treated by HHP are currently available on market (Ahmed et al., 2005; Barba et al., 2011; Bull et al., 2004; McInerney et al., 2007).

The effect of HHP can vary depending on processing conditions (pressure, hold time, temperature), food form (whole, pieces, juice, puree, mousse or smoothie) and intrinsic factor of food such as $\mathrm{pH}$. Grape, strawberry, apricot and apple polyphenol oxidase (PPO) seem to be more pressure sensitive than other PPO's. Apricot, strawberry and grape PPO can be inactivated by pressures exceeding 100, 400 and $600 \mathrm{MPa}$, respectively. Depending on $\mathrm{pH}$, pressures of $100-$ $700 \mathrm{MPa}$ were needed for the inactivation of apple PPO. There are many studies on thermal denaturation of PPO, but less data about the pressure inactivation of PPO are available. It is known that PPO may be activated or inactivated by HHP (Lopes et al., 2010).

HHP-processed fruits and fruit products may exhibit long-term changes in flavor, nutritional properties, and color as a result of the residual activity of endogenous enzymes (Boynton et al., 2002). To reduce enzyme activity and preserve food quality during processing and storage, different methods have been succesfully applied in combination with HHP, e.g. low $\mathrm{pH}$ conditions, refrigerated storage, high temperature treatment, 
and anti-browning agents (Guerrero-Beltrán et al., 2006; Krebbers et al., 2003).

\section{Effects of HHP on Phenolics of Fruits and Fruit Products}

Processing fruits and fruit products can change their content of phenolic compounds and heat treatments can reduce phenolic compounds in fruits and fruit products. Many factors affect the stability of the anthocyanins, including temperature, $\mathrm{pH}$, oxygen, enzymes, the presence of copigments and metallic ions, ascorbic acid, sulphur dioxide as well as sugars and their degradation products. Similarly, the behaviour of the polyphenol content is similar to that observed for the anthocyanin content in several liquids, semi-solid or solid foodstuffs (Ferrari et al., 2011). Great technological and research efforts have been made to obtain fruit juices by HHP without the quality and nutritional damage caused by heat treatments. Foods are processed in batch systems, in a pressure range of $50-1000 \mathrm{MPa}$; process temperature during pressure treatment can be from below 0 to above $100{ }^{\circ} \mathrm{C}$, while exposure time usually ranges from seconds to 20 minute (Corbo et al., 2009).

HHP treatment at ambient temperature is reported to have minimal effect on the anthocyanins content of various fruits and vegetables. Several authors have reported that the anthocyanins of different liquid foods are stable to HHP treatment at moderate temperatures. Impact of processing conditions affects the stability of phenolic compounds in fruits and their products. Matrix of food and processing parameters are important for retaining of phenolic compounds. Combination with other mild processing methods (ultrasound, gamma-irradiation, antimicrobial peptides) can help to retain nutritional and health-related characteristics of plant-derived products by assuring the safety of the product indeed during the storage period. The optimization of the HHP process conditions (pressure, temperature and time) is important for phenolic quantification (Tokusoglu et al., 2010; Corbo et al., 2009).

Several authors have reported the increased extractability of coloured pigments in food components at extreme pressures results polyphenol content increase. The authors attribute the increase of the total phenolic content to the release of some antioxidant components such as anthocyanins, amino acids and protein with phenolic hydroxyl group after HHP treatment from solid suspended particles following the high pressure processing. For semi-solid foods, the HHP treatment could potentially improve the total polyphenol content and prevent the degradation deriving from the application of high temperatures, as observed in traditional thermal treatments for food pasteurization/sterilization. This increase in total phenolic content (TPC) may be related to an increased extractability of some of the antioxidant components following high pressure processing. According to Le Chatelier's theory, the volume of system tends to be reduced during the pressure promoting period. In this process, the extracting solvent comes into cells to integrate with bioactive components. Besides, HHP can increase the rate of mass transfer resulting in an enhancement of solvent penetration into the cells by disrupting the cellular walls and hydrophobic bonds in the cell membrane, which may lead to a high permeability (Jun et al., 2009; Prasad et al., 2009; Cao et al., 2011).

Most of the studies showed that total phenolic compounds and some phenolic compounds (hesperetin, naringenin and anthocyanins) increased or unchanged by HHP. In general, several authors have proven that HHP on different fruit products (orange juice, lemon juice, apple juice, strawberry puree, kiwifruit puree, orange/carrot juice, apple/broccoli juice) slightly modified their content of phenolic compounds (Sánchez-Moreno et al., 2009; Cao et al., 2011; Barba et al., 2012). However, the effect of high pressure on the anthocyanin content of fruit derivatives cannot be generalized, while the composition of the product, the activity of the oxidative enzymes and the processing and operative conditions could compromise the efficiency of the HHP treatment. Enzymes such as polyphenoloxidase, peroxidase and $\beta$-glucosidase have been implicated in the degradation of phenolics and anthocyanins (Torres et al., 2011). Polyphenol oxidase (PPO) catalyses the hydroxylation of monophenols to o-diphenols and the oxidation of o-diphenols to o-quinones in the presence of molecular oxygen. The o-quinones are highly unstable and either react with high molecular weight polymers or form macromolecular complexes with amino acids and proteins (Terefe et al., 2009; Thomas-Barberan et al., 2001). Peroxidase (POD) catalyses the oxidation of phenolic compounds in the presence of hydrogen peroxides. Since the internal concentration of hydrogen peroxide in plants is low, the role of peroxidase in the in vivo degradation of 
J ournal abbreviation: J Food Health Sci

polyphenols is sometimes questioned. However, a synergistic activity of PPO and POD is possible with PPO acting as the promoter of POD since hydrogen peroxide is generated during the PPO catalysed oxidation of phenolic compounds (Thomas-Barberan et al., 2001).

\section{Effects of HHP on Anthocyanin Content of Fruit and Fruit products}

Anthocyanins were usually reported to be unstable, especially at high and abuse temperatures during processing and storage. Changes of phenolics and anthocyanins in fruits after HHP process are showed in Table 1. No significant change of anthocyanins is observed in strawberry halves after $600 \mathrm{MPa}$ HHP process. Changes of phenolics and anthocyanins in fruits juices, nectars and smoothies after HHP process are showed in Table 2. HHP effectively retained anthocyanins, phenolic compounds and color of pomegranete juice for treated samples with 350 $\mathrm{MPa}$ and $550 \mathrm{MPa}$ at room temperature (VarelaSantos et al., 2012). Alpas (2013) also observed no significant decrease in monomeric anthocyanin pigment concantrations for HHP samples, but thermal treatment $\left(85^{\circ} \mathrm{C} / 10 \mathrm{~min}\right.$. $)$ decreased significantly monomeric anthocyanin pigment concantrations in pomegranate juices. Greater retention of HHP samples is found compared to HTST $\left(110^{\circ} \mathrm{C} / 8.6 \mathrm{~s}\right)$ samples in cloudy pomegranate juice (Chen et al., 2013). In another study, $63 \%$ of pomegranate juice anthocyanins are retained after $400 \mathrm{MPa}$ HHP process. At the end of 21 and 72 days' storage, $65 \%$ and $63 \%$ of anthocyanins is retained at $4{ }^{\circ} \mathrm{C}$ (Ferrari et al., 2011). Anthocyanins of blueberry juice samples treated with $600 \mathrm{MPa}$ at $42^{\circ} \mathrm{C}$, increased significantly (Barba et al., 2011). No significant change of cyanidin-3-glucoside is observed for HHP treated blood orange juice (Torres et al., 2011). Changes of anthocyanins and total phenolics in fruit mousses and purees after HHP process showed in Table 3. No significant change in concentrations of anthocyanins is also observed for strawberry halves, strawberry and blackberry purees (Terefe et al., 2009; Patras et al., 2009b; Cao et al., 2011). Wild strawberry and strawberry mousses showed $89 \%$ retention of anthocyanins after $500 \mathrm{MPa} / 50^{\circ} \mathrm{C} / 10 \mathrm{~min}$. In another study, It is reported that the stability of strawberry and red raspberry anthocyanins, namely pelargonidin-3glucoside and pelargonidin-3-rutinoside, at 800 $\mathrm{MPa}$ for $15 \mathrm{~min}$. at moderate temperature (18$22^{\circ} \mathrm{C}$ ) may be due to complete inactivation of polyphenoloxidase (Pozo-Insfran et al., 2006). In contast to these findings, Terefe et al. (2013) and Talcott et al. (2003) showed significant loss of anthocyanins in strawberry puree and muscadine grape juice.

Table 1. Changes of anthocyanins and total phenolics in fruits after HHP process

\begin{tabular}{|c|c|c|c|c|c|}
\hline & \multirow{2}{*}{$\begin{array}{l}\text { Process and Storage } \\
\text { Conditions }\end{array}$} & \multicolumn{2}{|c|}{ Anthocyanin content } & \multirow[t]{2}{*}{ Total Phenolics } & \multirow[t]{2}{*}{ References } \\
\hline & & $\begin{array}{c}\text { After } \\
\text { Process }\end{array}$ & Storage & & \\
\hline $\begin{array}{l}\text { Strawberry } \\
\text { halves }\end{array}$ & $\begin{array}{l}600 \mathrm{MPa} / 60^{\circ} \mathrm{C} / 10 \mathrm{~min} . \\
3 \text { months storage at } \\
4^{\circ} \mathrm{C} \\
\end{array}$ & $\begin{array}{l}\text { No SN } \\
\text { effect }\end{array}$ & $27 \pm 10 \%$ decreased & $\begin{array}{l}\text { No SN effect after HHP treatment. } \\
22 \pm 13 \% \text { decreased at the end of } \\
\text { storage. }\end{array}$ & $\begin{array}{l}\text { Terefe et } \\
\text { al.,2009 }\end{array}$ \\
\hline Strawberry & $\begin{array}{l}200-800 \mathrm{MPa} / 18- \\
22^{\circ} \mathrm{C} / 15 \mathrm{~min} . \text {, storage } \\
\text { at } 4-30^{\circ} \mathrm{C} \text { for } 9 \text { days }\end{array}$ & & $\begin{array}{l}\text { Greater stability at } 800 \\
\mathrm{MPa} \text { for } \mathrm{P} 3 \mathrm{G} \text { and } \mathrm{P} 3 \mathrm{R} \text { at } \\
\text { storage temperature of } \\
4^{\circ} \mathrm{C} \text { for } 9 \text { days storage. }\end{array}$ & & $\begin{array}{l}\text { Zabetakis } \\
\text { et al. } 2000\end{array}$ \\
\hline Raspberry & $\begin{array}{l}200-800 \mathrm{MPa}, 18-22^{\circ} \mathrm{C}, \\
15 \text { min., storage at } 4- \\
30^{\circ} \mathrm{C} \text { for } 9 \text { days }\end{array}$ & & $\begin{array}{l}\text { Greater stability at } 800 \\
\mathrm{MPa} \text { for } \mathrm{C} 3 \mathrm{G} \text { and } \mathrm{C} 3 \mathrm{~S} \text { at } \\
\text { storage temperature of } \\
4^{\circ} \mathrm{C} \text { for } 9 \text { days storage. }\end{array}$ & & $\begin{array}{l}\text { Zabetakis } \\
\text { et al. } 2000\end{array}$ \\
\hline Blackcurrants & $\begin{array}{l}200-800 \mathrm{MPa} / 20- \\
22,5^{\circ} \mathrm{C} / 15 \mathrm{~min} ., \text { storage } \\
\text { at } 5-30^{\circ} \mathrm{C} \text { for } 7 \text { days }\end{array}$ & & $\begin{array}{l}\text { Best stability for C3R at } \\
600 \mathrm{MPa} 5^{\circ} \mathrm{C} \text {, for D3R at } \\
800 \mathrm{MPa} 5^{\circ} \mathrm{C} \text { for } \\
7 \text { days storage. }\end{array}$ & & $\begin{array}{l}\text { Kouniaki } \\
\text { et al. } 2004\end{array}$ \\
\hline
\end{tabular}

Anthocyanin content of phenolics generally reduces during storage. While anthocyanins of
HHP-treated cloudy pomegranate, pomegranate and strawberry juices are declining during storage, 
anthocyanins of HHP-treated blueberry juices showed no change even after 56 days' storage at $4^{\circ} \mathrm{C}$ (Chen et al., 2013; Zabetakis et al., 2000; Ferrari et al., 2011, Barba et al., 2011). Significantly higher loss of anthocyanins in HHP-treated cloudy strawberry juices were observed than in HHPtreated clear strawberry juices at $4^{\circ} \mathrm{C}$ storage, which was possibly due to higher concentrations of oxygen absorbed on pulp particles promoting the degradation of anthocyanins. Moreover, the loss of anthocyanins in both juices at $25^{\circ} \mathrm{C}$ were significantly higher than at $4^{\circ} \mathrm{C}$ and only less than $5 \%$ anthocyanins were retained in both juices after 6 months of storage at $25^{\circ} \mathrm{C}$, which mainly resulted from higher storage temperatures (Cao et al., 2012). Zabetakis al. (2000) also reported 15$20 \%, 50-60 \%$ and $70-80 \%$ decreases of anthocyanins in HHP-treated whole strawberry (200$800 \mathrm{MPa} / 15 \mathrm{~min} / 18-22^{\circ} \mathrm{C}$ ) after 7 days of storage at 4,20 and $30^{\circ} \mathrm{C}$, respectively. In addition, Ferrari et al. (2011) reported that retention of anthocyanins was $\% 72$ and $\% 75$ for wild strawberry mousses and strawberry mousses respectively after 21 days' storage, $4^{\circ} \mathrm{C}$ (Ferrari et al., 2011). The stability of anthocyanins can be due to a possible complete inactivation of polyphenoloxidase as reported for strawberry and red raspberry treated by HHP (Pozo-Insfran et al., 2006). Greater stability of several anthocyanins for raspberry, strawberry, blackcurrants was observed for 600-800 MPa amongst 200-800 MPa treated samples at $4-5^{\circ} \mathrm{C}, 7-9$ days' storage (Suthanthangjai et al., 2005; Zabetakis et al., 2000; Kouniaki et al., 2004). With all treatments, it is clear that the extent of anthocyanins losses were lowest when fruits and fruit products were stored at $4^{\circ} \mathrm{C}$. Authors mostly reported that anthocyanins are stable to HHP treatment at moderate temperatures, while anthocyanin degradation generally occurs during the storage of the processed foodstuffs. Loss of anthocyanins was probably due to oxidation as well as condensation of anthocyanin pigments with phenolic compounds. Due to the residual oxygen concentration and the activity of polyphenol oxidase and peroxidase, a decreasing trend can be seen during storage. Condensation reactions of anthocyanins with other phenolics naturally occurred in juices with storage times, phenolic acids such as ferulic and syringic acids showed complexities with anthocyanins in strawberry and raspberry juices and condensation products were unstable and further degrade to colorless compounds. The stability of anthocyanins was also influenced by other fruit components, particularly the interaction of ascorbic acid with anthocyanins. The degredation of anthocyanins induced by ascorbic acid was hypothesized to result indirectly from hydrogen peroxide formation during oxidation of ascorbic acid, which could trigger nucleophilic attack of the C2 of anthocyanins, and finally cause its ring open into check ketone (Castaňeda-Ovando et al., 2009; Rein et al., 2005).

\section{Effects of HHP on total phenolic content (TPC) of fruits and fruit products}

The effects of thermal and high hydrostatic pressure (HHP) processing on phenolics of fruits, fruit juices, nectars, purees, mousses, smoothies were assessed by several studies. Total phenolic content (TPC) of pomegranate juice increased significantly after 350 and $500 \mathrm{MPa} / 30-150 \mathrm{~s}$. HHP process. TPC showed an increase in the first 3 days and started to decrease after 5 days for HHP samples. TPC of control samples was also decreased during storage at $4^{\circ} \mathrm{C}$ (Varela-Santos et al., 2012). In addition, significant increase of phenolics after 300-400 $\mathrm{MPa} / 2.5-25 \mathrm{~min}$. treatment was observed in cloudy pomegranate juice (Chen et al., 2013). Alpas (2013) also studied pomegranate juices at $200-400 \mathrm{MPa} / 5-25^{\circ} \mathrm{C} / 5-10$ min., no significant change was reported for HHP samples, while significant decrease of phenolics was reported for $\mathrm{TT}\left(85^{\circ} \mathrm{C} / 10 \mathrm{~min}\right.$.).

Changes of anthocyanins and total phenolics in fruit juices, nectars and smoothies after HHP process demonstrated in Table 2. Orange-juice milk beverage showed significant and nonsignificant increases for 100-400 MPa HHP treatments and thermal treatments following 90$98^{\circ} \mathrm{C}, 15-21 \mathrm{~s}$. In addition, TPC of smoothie, mix of papaya, melon juices, carrot puree and skimmed milk, after 450-600 MPa HHP treatment increased (Andres et al., 2015). After process, TPC of HHP smoothies was slightly higher $(\approx 11 \%$ ) compared to TT samples (Keenan et al., 2010; Keenan et al., 2012). Likewise, orange juice milk beverage and smoothies, TPC of prickly pear beverage, apricot nectar and litchi juice increased after HHP process (Jimenez-Aguilar et al., 2015; Huang et al., 2013; Zheng et al., 2014). HHP treatments increased total and individual phenolics in apricot nectars, which were significantly lower than those in HTST-treated apricot nectars (Huang et al., 2013). While HHP increased TPC in litchi juice, a fermented fruit juice, TPC decreased by TT. During 4 weeks of storage at 
Journal abbreviation: J Food Health Sci

$4^{\circ} \mathrm{C}$, TPC in heat treated litchi juice showed a tendency to slowly decrease, while a slight fluctuation is observed in TPC of HHP-treated litchi juice (Zheng et al., 2014). Barba et al. (2011) reported that TPC in HHP-treated and untreated blueberry juice showed no change after process. Likewise, TPC of mango nectar did not change after HHP
(600MPa/1min.) and HTST $\left(110^{\circ} \mathrm{C} / 8.6 \mathrm{~s}\right)$. During 56 days' storage of blueberry juices at $4^{\circ} \mathrm{C}$, fluctuations in the TPC were observed for all blueberry juice samples. After 16 weeks' storage, TPC decreased by 19.11 and $27.94 \%$ in HHPtreated samples, and by 17.03 and $25.23 \%$ in HTST-treated samples at 4 and $25^{\circ} \mathrm{C}$, respectively.

Table 2. Changes of anthocyanins and total phenolics in fruit juices, nectars and smoothies after HHP process

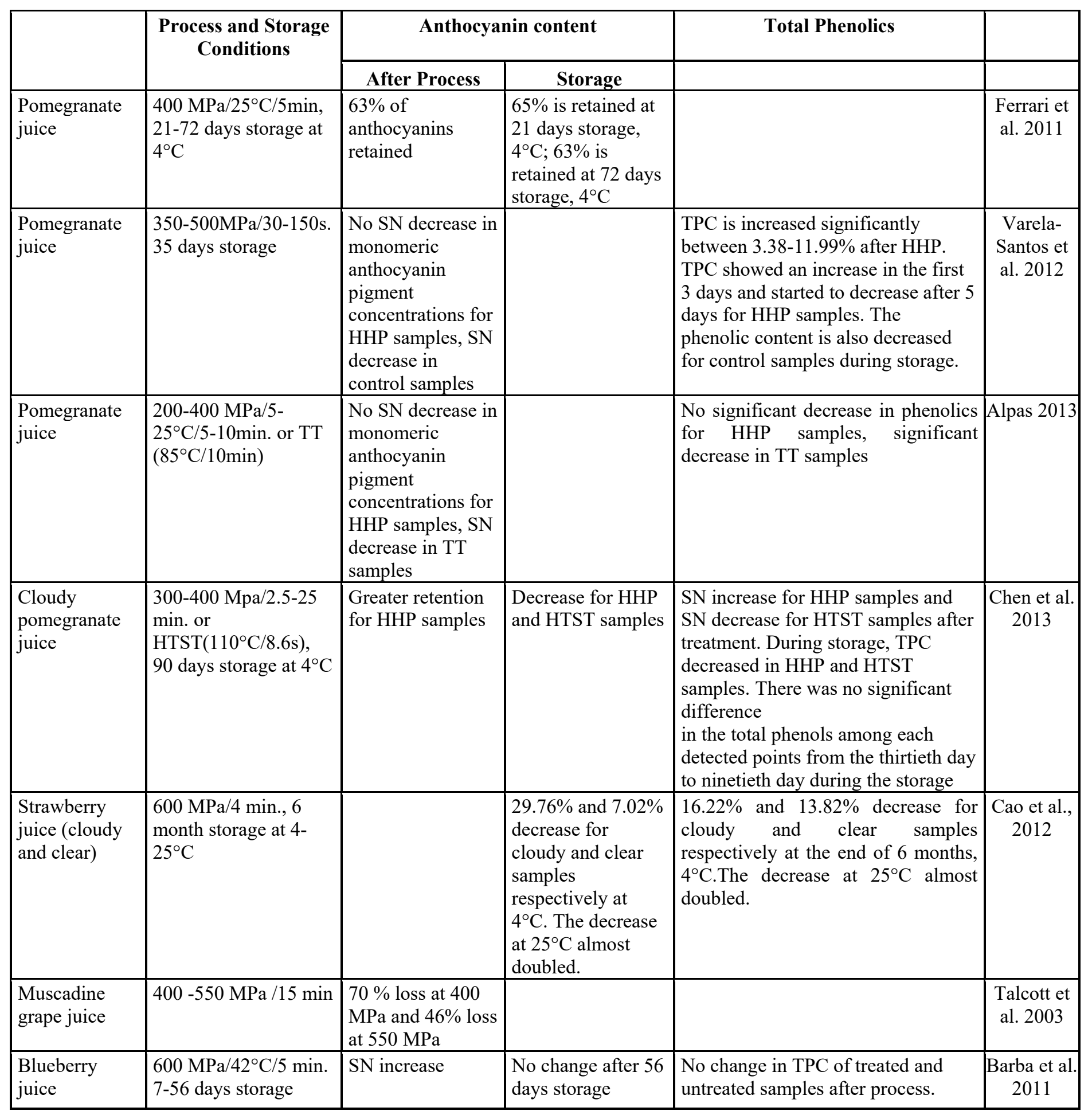


J ournal abbreviation: J Food Health Sci

\begin{tabular}{|c|c|c|c|c|c|}
\hline & & & & $\begin{array}{l}\text { During 56-day storage at } 4{ }^{\circ} \mathrm{C} \\
\text { fluctuations in the TPC were } \\
\text { observed for all juices. } \\
\end{array}$ & \\
\hline $\begin{array}{l}\text { Blood orange } \\
\text { juice }\end{array}$ & $\begin{array}{l}400-600 \mathrm{MPa} / 15 \mathrm{~min}, \\
\text { storage at } 4,20^{\circ} \mathrm{C}\end{array}$ & $\begin{array}{l}>\% 99 \text { retention } \\
\text { of } \mathrm{C} 3 \mathrm{G} \text { is } \\
\text { observed }\end{array}$ & $\begin{array}{l}\text { Greater stability at } \\
500 \mathrm{MPa} \text { for } \mathrm{C} 3 \mathrm{G} \\
\text { at } 4^{\circ} \mathrm{C} \text { for } 10 \text { days } \\
\text { storage }\end{array}$ & & $\begin{array}{l}\text { Torres et } \\
\text { al. } 2011\end{array}$ \\
\hline $\begin{array}{l}\text { Orange juice- } \\
\text { milk beverage }\end{array}$ & $\begin{array}{l}100-400 \mathrm{MPa} \text { for } \\
120-540 \text { s or TT(}(90- \\
\left.98^{\circ} \mathrm{C} / 15-21 \mathrm{~s}\right)\end{array}$ & & & $\begin{array}{l}\text { SN and NSN increases for all HHP } \\
\text { treatments except } 400 \mathrm{Mpa}, 540 \mathrm{~s} \\
\text { SN and NSN increases for all TT }\end{array}$ & $\begin{array}{c}\text { Barba et al. } \\
2012\end{array}$ \\
\hline Litchi juice & $\begin{array}{l}\text { 500Mpa/2min. or TT } \\
\left(95^{\circ} \mathrm{C} / 1 \mathrm{~min}\right) .4 \text { weeks } \\
\text { storage }\end{array}$ & & & $\begin{array}{l}\text { NSN increase in TPC after HHP } \\
\text { treatment, decrease after TT. The } \\
\text { content of total phenolics in } \\
\text { fermented heat-treated } \\
\text { litchi juice showed a tendency to } \\
\text { slowly decrease during } 4 \text { weeks of } \\
\text { storage at } 4^{\circ} \mathrm{C} \text {, while a slight } \\
\text { fluctuation in the content of total } \\
\text { phenolics of fermented HHP-treated } \\
\text { litchi juice during } 4 \text { weeks of storage } \\
\text { at } 4^{\circ} \mathrm{C} \text { was observed. }\end{array}$ & $\begin{array}{l}\text { Zheng et } \\
\text { al.2014 }\end{array}$ \\
\hline $\begin{array}{l}\text { Prickly pear } \\
\text { beverage }\end{array}$ & $\begin{array}{l}400-550 \mathrm{MPa} / 0.3-16 \\
\text { min. }\end{array}$ & & & $\begin{array}{l}\text { SN increase in } 550 \mathrm{MPa} / \mathrm{t} \geq 2 \mathrm{~min} \text {. } \\
\text { samples }\end{array}$ & $\begin{array}{l}\text { Jimenez- } \\
\text { Aguilar et } \\
\text { al., } 2015 \\
\end{array}$ \\
\hline Apricot nectar & $\begin{array}{l}300-500 \mathrm{MPa} / 5-20 \\
\text { min. or HTST( } \\
\left.110^{\circ} \mathrm{C} / 8.6 \mathrm{~s}\right)\end{array}$ & & & $\begin{array}{l}\text { HHP treatments increased total and } \\
\text { individual phenolics } \\
\text { in apricot nectars, which were } \\
\text { significantly lower than those in } \\
\text { HTST-treated apricot nectars. }\end{array}$ & $\begin{array}{l}\text { Huang et } \\
\text { al. } 2013\end{array}$ \\
\hline Mango nectar & \begin{tabular}{|l|}
$600 \mathrm{MPa} / 1 \mathrm{~min}$ or \\
$\mathrm{HTST}\left(110^{\circ} \mathrm{C} / 8.6 \mathrm{~s}\right)$ \\
16 weeks storage at 4 \\
and $25^{\circ} \mathrm{C}$, steam \\
blanching was \\
implemented prior \\
both HHP and HTST
\end{tabular} & & & $\begin{array}{l}\text { No SN changes IN TPC after HHP } \\
\text { or HTST.After } 16 \text { weeks storage, } \\
\text { TPC decreased by } 19.11 \text { and } 27.94 \% \\
\text { in HHP-treated samples, and by } \\
17.03 \text { and } 25.23 \% \text { in HTST-treated } \\
\text { samples at } 4 \text { and } 25^{\circ} \mathrm{C} \text {, respectively. }\end{array}$ & $\begin{array}{l}\text { Liu et al. } \\
2014\end{array}$ \\
\hline Fruit smoothie & $\begin{array}{l}450-600 \mathrm{MPa} / 20 \\
{ }^{\circ} \mathrm{C} / 1-120 \mathrm{~min} . \text { or } \\
\mathrm{TT}\left(\mathrm{P}_{70}>10 \mathrm{~min}\right)\end{array}$ & & & $\begin{array}{l}\text { TPC of HPP smoothies (450 MPa;5 } \\
\text { min) was slightly higher }(\sim 11 \%) \\
\text { compared to TT samples. }\end{array}$ & $\begin{array}{l}\text { Keenan et } \\
\text { al. } 2010 \text {; } \\
\text { Keenan et } \\
\text { al.2012 } \\
\end{array}$ \\
\hline $\begin{array}{l}\text { Smoothie (mix } \\
\text { of papaya, } \\
\text { melon juices, } \\
\text { carrot puree } \\
\text { and skimmed } \\
\text { milk) } \\
\end{array}$ & $\begin{array}{l}450-600 \mathrm{MPa} / 20^{\circ} \mathrm{C} / 3 \\
\min \text { or } \mathrm{TT}\left(80^{\circ} \mathrm{C} / 3\right. \\
\min .), 45 \text { days storage } \\
\text { at } 4^{\circ} \mathrm{C}\end{array}$ & & & $\begin{array}{l}\text { TPC increased after HHP treatment. } \\
\text { TPC decreased } 15 \%, 12 \%, 11 \% \text { and } \\
8 \% \text { for untreated, HHP- } 450 \text {, HHP- } \\
600 \text { and TT samples respectively at } \\
\text { the end of storage period. }\end{array}$ & $\begin{array}{l}\text { Andrés et } \\
\text { al. } 2015\end{array}$ \\
\hline
\end{tabular}


Journal abbreviation: J Food Health Sci

Table 3. Changes of anthocyanins and total phenolics in fruit mousses and purees after HHP process

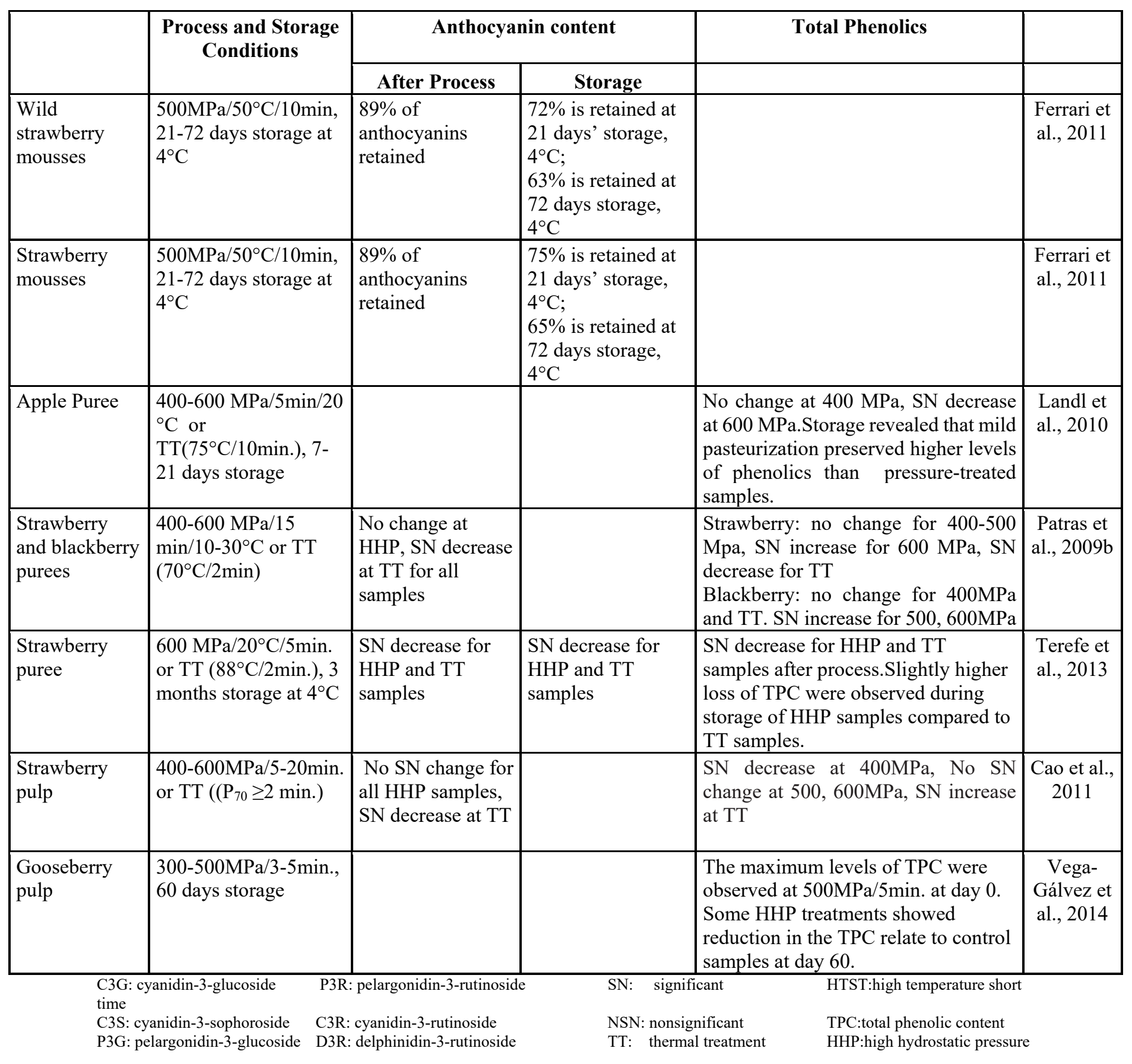




\section{J ournal abbreviation: J Food Health Sci}

In table 3 , changes of anthocyanins and total phenolics in fruit mousses and purees after HHP process is showed. The maximum TPC in gooseberry pulp was observed after $500 \mathrm{MPa} / 5 \mathrm{~min}$. HHP amongst 300-500 MPa/3-5 min. HHP treatments. Some of HHP-treated samples had higher TPC some of them had lower TPC than control samples (Vega-Gálvez et al., 2014). Similar results were obtained for apricot nectars and apple puree (Huang et al., 2013). TPP content of apple puree was not changed during processing at $400 \mathrm{MPa}$, but was affected by the $600 \mathrm{MPa}$ and also slightly by the pasteurization (Landl et al., 2010). Based on these results, it can be concluded that HHP treatment, due to changes in fruit pulp microstructure, produces changes in the distribution and aggregation of phenolic compounds. High pressure treatment can increase the rate of mass transfer in an enhancement of solvent penetration into the cells by disrupting the cellular walls and hydrophobic bonds in cell membrane, which may lead to a high permeability (Prasad et al., 2009). Thus, the increase in total phenols may be related to an increased extractability of some antioxidant components such as anthocyanins, amino acids and protein with phenolic hydroxyl group after HHP treatment (Cao et al., 2011).

TPC of strawberry purees and pulps showed different trends after HHP treatments (Patras et al., 2009b; Terefe et al., 2013; Cao et al., 2011). TPC of strawberry purees increased at $600 \mathrm{MPa} / 10$ $30^{\circ} \mathrm{C} / 15$. min., while TPC of strawberry purees showed no change for $400-500 \mathrm{MPa} / 10-30^{\circ} \mathrm{C} / 15$ minutes (Patras et al., 2009b). Likewise, Cao et al. (2011) reported no significant change in TPC following HPP (400-600MPa/5-25min.) In contrast, Terefe et al. (2013) observed significant decrease at $600 \mathrm{MPa} / 20^{\circ} \mathrm{C} / 5 \mathrm{~min}$. Terefe et al. (2013) attributed to homogenized strawberry puree samples with substantial tissue disruption, which allowed significant enzyme-substrate interaction during processing due to tissue decompartmentalisation. In addition, the strawberry halves, which showed no significant change in TPC after HHP, were vacuum packed limiting the availability of oxygen for oxidation (Terefe et al., 2009). These may explain the observed difference between Terefe et al. (2013) and other studies in the literature like that of Terefe et al. (2009) and Patras et al. (2009b) where the samples were vacuum packed. Patras et al. (2009b) and Terefe et al. (2013) reported that thermal treatment caused significant decrease in TPC of strawberry purees, while Cao et al. (2011) reported significant increase in TPC of thermally treated strawberry pulps. Cao et al. (2012) reported that TPC of $600 \mathrm{MPa} / 4 \mathrm{~min}$. HHP-treated cloudy and clear strawberry juices decreased $16.22 \%$ and $13.82 \%$ respectively at the end of 6 months' storage, $4^{\circ} \mathrm{C}$. The decrease at $25^{\circ} \mathrm{C}$ almost doubled, which was due to decomposition of total phenols induced by higher temperatures during storage (Cao et al., 2012). Normally, polyphenol oxidase and peroxidase were considered to be the main enzymes responsible for the decay of phenols in processed fruits and their derived foods. However, these two enzymes could totally inactivate in blanching, and no enzymatic degradation of total phenols was present in some studies. The decrease of total phenols attributed to the oxidation degradation of phenolic compounds and the polymerization of phenolic compounds with proteins (Cao et al., 2011).

Enzymatic oxidation (polyphenol oxidase and peroxidase) and non-enzymatic autooxidation are responsible of phenolics deterioration. For several PPO enzymes, it has been reported that pressureinduced inactivation proceeds faster at lower $\mathrm{pH}$ however the inactivation is also influenced by the addition of salts, sugars or other things. However, it must be noted that the effect of HHP processing parameters such as pressure, temperature and time along with physicochemical properties of fruit such as total soluble solids and $\mathrm{pH}$ have varying effects on the enzymes responsible for anthocyanins and phenolics stability in HHP processed fruits and fruit products (Pozo-Insfran et al., 2006).

\section{Conclusions and Future Trends}

Phenolic compounds are healthy substances and food industry aims to preserve these compounds and decrease losses of these substances. HHP of fruits and vegetables has been revealed as a useful tool to extend their shelf life and quality as well as to preserve their nutritional and functional characteristics.

Impact of processing conditions and matrix of food on the stability of phenolic compounds in fruits and their products after the process and during storage are very important. It is considered that HHP results in better retention of phenolics and anthocyanins compared to thermal treatments, although some studies indicate that this may not be true in all cases. Processing conditions such as pressure, time, temperature and food-related traits 
such as food matrix, $\mathrm{pH}$ affects retention of phenolic compounds.

HHP generally proves itself compared to heat treatment in preserving phenolic compounds, but it depends on processing conditions. Further research will be necessary for exploring new applications of HHP technologies, not only to improve the sensorial quality and stability of foods as the main objective, but also to obtain healthy products which have more amounts of bioactive substances like phenolic compounds by preserving them as much as possible during processing. Processing conditions of HHP such as pressure, temperature, time, that increases or stabilizes phenolic compounds, should be studied and determined for more fruit and fruit products. Modelling of HHP conditions for maximum phenolic increase or retainment in different fruits and fruit products would be beneficial.

\section{References}

Ahmed, J., Ramaswamy, H.S., \& Hiremath, N. (2005). The effect of high pressure treatment on rheological characteristics and colour of mango pulp. International Journal of Food Science and Technology, 40, 885-895.

Alpas, H., (2013). Effect of high hydrostatic pressure processing (HHP) on quality properties, squeezing pressure effect and shelf life of pomegranate juice. Poster Presentation. Current Opinion in Biotechology, s111.

Andrés, V., Villanueva, M.J., \& Tenorio, M.D., (2016). The effect of high-pressure processing on colour, bioactive compounds, and antioxidant activity in smoothies during refrigerated storage. Food Chemistry, 192, 328-335.

Bala, B., Farkas, D., \& Turek, E.J., (2008). Preserving foods through high-pressure processing. Food Technology, 11, 32-38.

Barba, F.J., Jager, H., Meneses, N., Esteve, M.J., \& Frígola, A., Knorr, D., (2012), Evaluation of quality changes of blueberry juice during refrigerated storage after high-pressure and pulsed electric fields processing. Innovative Food Science and Emerging Technologies, 14, 18-24.

Barba, F.J., Cortes, C., Esteve, M.J., \& Frigola, A., (2012). Study of antioxidant capacity and quality parameters in an orange juice-milk beverage after high-pressure processing treatment. Food and Bioprocess Techology, 5, 2222-2232.

Barba, F.J., Jager, H., Meneses, N., Esteve, M.J., Frigola, A., \& Knorr, D. (2011). Evaluation of quality changes of blueberry juice during refrigerated storage after high-pressure and pulsed electric fields processing. Innovative Food Science and Emerging Technologies, 14, 18-24.

Boynton, B.B., Sims, C.A., Sargent, S., Balaban, M.O., \& Marshall, M.R., (2002). Quality and stability of precut mangos and carambolas subjected to high-pressure processing. Sensory and Nutritive Qualities of Food, 67(1), 409-415.

Bull, M.K., Zerdin, K., Howe, E., Goicoechea, D., Paramanandhan, P., Stockman, R., Sellahewa, J., Szabo, E.A., Johnson, R. L., \& Stewart, C.M., (2004). The effect of high pressure processing on the microbial, physical and chemical properties of Valencia and Navel orange juice. Innovative Food Science and Emerging Technologies, 5, 135149.

Burrows, G., (2001). Production of thermally processed and frozen fruit. In: Arthey, D., Ashurst, P. R. (Eds.), Fruit Processing: Nutrition, products, and quality management, 2nd ed. Gaithersburg, Maryland: Aspen publishers, pp. 149-176.

Castañeda-Ovando, A., Pacheco-Hernández, M.L., Páez-Hernández, M. E., Rodríguez, J.A., \& Galán-Vidal, C.A., (2009). Chemical studies of anthocyanins: A review. Food Chemistry, 113, 859-871.

Cao, X., Bi, X., Huang, W., Wu, J., Hu, X., \& Liao, X., (2012). Changes of quality of high hydrostatic pressure processed cloudy and clear strawberry juices during storage. Innovative Food Science and Emerging Technologies, 16, 181-190.

Cao, X., Zhang, Y., Zhang, F., Wang, Y., Yi, J, \& Liao, X., (2011). Effects of high hydrostatic pressure on enzymes, phenolic compounds, anthocyanins, polymeric colour and colour of strawberry pulps. Journal of the Food Science of Food and Agriculture. 91, 877885.

Chen, D., Xi, H., Guo, X., Qin, Z., Pang,X., Hu, X., Liao, X., \& Wu, J., (2013). Comparative 
study of quality of cloudy pomegranate juice treated by high hydrostatic pressure and high temperature short time. Innovative Food Science and Emerging Technologies, 19, 8594.

Corbo, M.R., Bevilacqua, A., Campaniello, D., D’Amato, D., Speranza, B., \& Sinigaglia, M., (2009). Prolonging microbial shelf life of foods through the use of natural compounds and non-thermal approaches. International Journal of Food Science and Technology, 44, 223-241.

FDA, (2014). Kinetics of Microbial Inactivation for Alternative Food Processing Technologies -- High Pressure Processing. U.S. Food and Drug Administration, http://www.fda.gov/Food/FoodScienceResea $\underline{\mathrm{rch} / \text { SafePracticesforFoodProcesses/ucm } 101}$ $\underline{456 . h t m}$

Ferrari, G., Maresca, P., \& Ciccarone, R., (2011). The effects of high hydrostatic pressure on the polyphenols and anthocyanins in red fruit products. Procedia Food Science, 1, 847853.

García-Viguera, C., \& Bridle, P., (1999). Influence of structure on colour stability ofanthocyanins and flavylium salts with ascorbic acid. Food Chemistry, 64(1), 21-26.

Guerrero-Beltrán, J.A., Barbosa-Cánovas, G. V., Moraga-Ballesteros, G., Moraga-Ballesteros, M.J., \& Swanson, B.G., (2006). Effect of pH and ascorbic acid on high hydrostatic pressure-processed mango puree. Journal of Food Processing and Preservation, 30(5), 582-596.

Huang, W., Bi, X., Zhang, X., Liao, X., Hu, X., \& Jihong, W., (2013). Comparative study of enzymes, phenolics, carotenoids and color of apricot nectars treated by high hydrostatic pressure and high temperature short time. Innovative Food Science and Emerging Technologies, 18, 74-82.

Jimenez-Aguilar, D.M., Escobedo-Avellaneda, Z., Martin-Belloso, O. Gutierrez-Uribe, J., Valdez-Fragoso, A., Garcia-Garcia, R., Torres, J.A., \& Welti-Chanes, J., (2015). Effect of high hydrostatic pressure on the content of phytochemical compounds and antioxidant activity of prickly pears (Opuntia ficus-indica) beverages. Food Engineering Reviews, 7, 198-208.
Jun, X., Deji, S., Shou, Z., Bingbing, L., Ye, L., \& Rui, Z., (2009). Characterization of polyphenols from gren tea leaves uing a high hydrostatic pressure extraction. International Journal of Pharmaceutics, 382, 139-143.

Keenan, D.F., Brunton, N.P., Gormley, T.R., Butler, F., Tiwari, B.K., \& Patras, A. (2010). Effect of thermal and high hydrostatic pressure processing on antioxidant activity and colour of fruit smoothies. Innovative Food Science and Emerging Technologies, 11, 551-556.

Keenan, D.F., Rößle, C., Gormley, R., Butler, F., \& Brunton, N.P. (2012): Effect of high hydrostatic pressure and thermal processing on the nutritional quality and enzyme activity of fruit smoothies. LWT-Food Science and Technology, 45: 50-57.

Kouniaki, S., Kajda, P., \& Zabetakis, I., (2004). The effect of high hydrostatic pressure on anthocyanins and ascorbic acid in blackcurrants (Ribes nigrum). Flavour and Fragrance Journal, 19, 281-286.

Krebbers, B., Matser, A.M., Hoogerwerf, S.W., Moezelaar, R., Tomassen, M.M.M., \& Vanden Berg, R.W., (2003). Combined highpressure and thermal treatments for processingof tomato puree: evaluation of microbial inactivation and quality parameters. Innovative Food Science and Emerging Technologies, 4(4), 377-385.

Landl, A., Abadias, M., Sárraga, C., Viñas, I., \& Picouet, P.A., (2010). Effect of high pressure processing on the quality of acidified Granny Smith apple purée product. Innovative Food Science and Emerging Technologies, 11, 557-564.

Liu, F., Wang, Y., Li, R., Bi, X., \& Liao, X., (2014). Effects of high hydrostatic pressure and high temperature short time on antioxidant activity, antioxidant compounds and color of mango nectars. Innovative Food Science and Emerging Technologies, 21, 3543.

Lopes M.L.M., Mesquita, V.L.V., \& Chiaradia, A.C.N., Fernandes, A.A.R., Fernandes, P.M.B., (2010). High hydrostatic pressure processing of tropical fruits Importance for maintenance of the natural food properties. In: Braaten, D. (Eds.), Annals of The New York Academy of Sciences Issue: High- 
Journal abbreviation: J Food Health Sci

Pressure Bioscience and Biotechnology, The New York Academy of Sciences, pp. 6-15.

McInerney, J. K., Seccafien, C. A., Stewart, C. M., \& Bird, A.R., (2007). Effects of high pressure processing on antioxidant activity, and total carotenoid content and availability in vegetables. Innovative Food Science and Emerging Technologies, 8, 543-548.

Michels, K.V., Giovannucci, E., Joshipura, K.J., Rosner, B.A., Stampfer, M.J., Fuchs, C.S., Colditz, G.A., Speizer, F.E., \& Willett, W.C., (2000). Prospective study of fruit and vegetable consumption and incidence of colon and rectal cancers. Journal of the National Cancer Institute, 92, 17401752.

Oey, I., Lille, M., Van Loey, A., \& Hendrickx, M., (2008). Effect of high pressure processing on colour, texture and flavour of fruit and vegetable-based food products: a review. Trends in Food Science \& Technology, 19, 320-328.

Patras, A., Brunton, N., Pieve, S.D., Butler, F., \& Downey, G., (2009a). Effect of thermal and high pressure processing on antioxidant activity and instrumental colour of tomato and carrot purees, Innovative Food Science and Emerging Technologies, 10, 16-22.

Patras, A., Brunton, N.P., Pieve, S., \& Butler F., (2009b). Impact of high pressure on total antioxidant activity, phenolic, ascorbic acid, anthocyanin content and colour of strawberry and blackberry purees. Innovative Food Science and Emerging Technologies, 10, 308-313.

Prasad, K.N., Yang, E., Yi, C., Zhao, M., \& Jiang, Y., (2009). Effect of high pressure extraction on the extraction yield, total phenolic content and antioxidant activity of longan fruit pericarp. Innovative Food Science and Emerging Technologies, 10(2), 155-159.

Pozo-Insfran, D.D., (2006). Emerging Technologies and Strategies to Enhance Anthocyanin Stability. Doctoral Dissertation University of Florida, 1-144.

Ramirez, R., Saraiva, J.A., Perez Lamela, C., \& Torres, J.A., (2009). Reaction kinetics analysisof chemical changes in pressureassisted thermal processing. Food Engineering Reviews, 1(1), 16-30.
Rein, M.J., Ollilainen, V., Vahermo, M., YliKauhaluoma, J., \& Heinonen, M., (2005). Identification of novel pyranoanthocyanins in berry juices. European Food Research and Technology, 220, 239-244.

Sánchez-Moreno, C., Ancos, B., Plaza, L., ElezMartínez, P., \& Cano, M.P., (2009). Nutritional approaches and health-related properties of plant foods processed by high pressure and pulsed electric fields. Critical Reviews in Food Science and Nutrition, 49, 552-576.

Suthanthangjai, W., Kajda, P., \& Zabetakis, I., (2005). The effect of high hydrostatic pressure on the anthocyanins of raspberry (Rubus idaeus). Food Chemistry, 90, 193197.

Talcott, S.T., Brenes, C.H., Pires, D.M., \& PozoInsfran, D.D., (2003). Phytochemical stability and color retention of copigmented and processed muscadine grape juice. Journal of Agricultural and Food Chemistry, 51, 957-963.

Terefe, N.S., Matthies, K., Simons, L., \& Versteeg, C., (2009), Combined high pressure-mild temperature processing for optimal retention of physical and nutritional quality of strawberries (Fragaria $\times$ ananassa). Innovative Food Science and Emerging Technologies, 10, 297-307.

Terefe, N. S., Kleintschek, T., Gamage, T., Fanning, K.J., Netzel, G., Versteeg, C., \& Netzel, M., (2013). Comparative effects of thermal and high pressure processing on phenolic phytochemicals in different strawberry cultivars. Innovative Food Science and Emerging Technologies, 19, 57 65.

Tokusoglu, O., Alpas, H., \& Bozoglu, F., (2010). High hydrostatic pressure effects on mold flora, citrinin mycotoxin, hydroxytyrosol, oleuropein phenolics and antioxidant activity of black table olives. Innovative Food Science and Emerging Technologies, 11, 250-258.

Tomás-Barberán, F.A., \& Espín, J.C., (2001). Phenolic compounds and related enzymes as determinants of quality in fruits and vegetables. Journal of the Science of Food and Agriculture, 81(9), 853-876. 
J ournal abbreviation: J Food Health Sci

Torres, B., Tiwari, B.K., Patras, A., Cullen, P.J., Brunton, N., \& O’Donnell, C.P., (2011). Stability of anthocyanins and ascorbic acid of high pressure processed blood orange juice during storage. Innovative Food Science and Emerging Technologies, 12, 93-97.

Varela-Santos, E., Ochoa-Martinez, A., TabiloMunizaga, G., Reyes, J.E., Pérez-Won, M., Briones-Labarca, V., \& Morales-Castro, J., (2012). Effect of high hydrostatic pressure (HHP) processing on physicochemical properties, bioactive compounds and shelflife of pomegranate juice. Innovative Food Science and Emerging Technologies, 13, 1322.

Vega-Gálvez, A., López, J., Torres-Ossandón, M. J., Galotto, M. J., Puente-Díaz, L., Quispe-
Fuentes, I., \& Scala, K., (2014). High hydrostatic pressure effect on chemical composition, color, phenolic acids and antioxidant capacity of Cape gooseberry pulp (Physalis peruviana L.). LWT-Food Science and Technology, 58, 519-526.

Zabetakis, I., Leclerc, D., \& Kajda, P., (2000). The effect of high hydrostatic pressure on the strawberry anthocyanins. Journal of Agriculture and Food Chemistry, 48, 27492754.

Zheng, X., Yu, Y., Xiao, G., Xu, Y., Wu, J., Tang, D., \& Zhang, Y., (2014). Comparing product stability of probiotic beverages using litchi juice treated by high hydrostatic pressure and heat as substrates. Innovative Food Science and Emerging Technologies, 23, 61-67. 